\title{
Dezessete: a Maçonaria dividida
}

\section{Evaldo Cabral de Mello}

$\mathrm{A}_{\text {controle da maçonaria portuguesa e fluminense. A Grande Loja Por- }}^{\text {revoluão de } 1817 \text { em Pernambuco foi um movimento que fugiu ao }}$ tuguesa ou Grande Oriente Maçônico compunha-se majoritariamente de elementos da nobreza, das forças armadas e do clero. Tendo sobrevivido, após a ocupação francesa de Lisboa, à repressão desencadeada pela regência do Reino, a maçonaria lusitana recuperara-se a partir de 1813, na esteira do regresso do Exército português que lutara sob Wellington na Península Ibérica, fundando-se novas lojas e reorganizando-se a instituição de cúpula. À reestruturação em Portugal, seguiu-se a do Rio, cujas lojas, fechadas em 1806 no governo do conde dos Arcos, reabriram-se após a chegada do Príncipe Regente, graças à tolerância e a cumplicidade de altos funcionários do regime, como d. Rodrigo de Sousa Coutinho, que, como tantos outros, era tido e havido na conta de pedreiro-livre ou, ao menos, de simpático a eles. Criou-se então o Grande Oriente Brasileiro, que teve um futuro protagonista de Dezessete, Antônio Carlos Ribeiro de Andrada, como seu primeiro grão-mestre.

Mas ao contrário da maçonaria fluminense, a pernambucana escapou ao controle do Grande Oriente Lusitano. ${ }^{1}$ Seu aparecimento datava também dos primeiros anos do século, sob o estímulo do naturalista Manuel Arruda da Câmara e do seu discípulo, padre João Ribeiro. ${ }^{2}$ Mas foi igualmente a partir de 1813 que ela foi reativada não de Lisboa ou do Rio, mas de Londres, por Domingos José Martins, emissário de pedreiros-livres ingleses. Desde então as lojas pernambucanas tornaram-se exclusivamente brasileiras, excluindo os portugueses, os quais por isso mesmo fizeram a sua à parte. Martins e seus aliados, o mesmo padre João Ribeiro, o negociante Cabugá e o médico Guimarães Peixoto, trataram de conquistar o clero e a oficialidade, empresa tanto mais fácil quanto essas categorias já se compunham majoritariamente de naturais da terra, estando predispostas, portanto, a se constituírem em ponta-de-lança do projeto emancipacionista. ${ }^{3}$ 
Que a maçonaria pernambucana recebesse seu impulso de Londres e não de Lisboa é relevante para compreender Dezessete. Embora houvesse sido uma criação da maçonaria inglesa, a Grande Loja Portuguesa caíra progressivamente sob a influência do Grande Oriente de França, com quem assinara o tratado de cooperação de 1804 , ao passo que a concorrente britânica cindira-se em lojas rivais devido a divergências em matéria de ritual, cisão apenas superada em 1813. Como acentuou A. H. de Oliveira Marques, "a intervenção britânica neste campo deve entender-se também como uma estratégia complexa onde imperialismo maçônico e imperialismo político andavam de mãos dadas". ${ }^{4}$ É provável, por conseguinte, que a missão de Domingos José Martins a Pernambuco tivesse visado precisamente a criar uma alternativa pró-britânica ao Grande Oriente do Brasil e ao Grande Oriente de Lisboa, revidando à intenção declarada dos pedreiros-livres do Reino de liquidarem a posição privilegiada da Inglaterra no Império lusobrasileiro, intenção que se manifestará com força na frustrada conspiração maçônica de Gomes Freire de Andrade, também em 1817.

Nos primeiros dias da insurreição, prevalecia na província a impressão de que o movimento se fizera não contra El-Rei mas contra seus agentes, como observou Tollenare: "Um grande número de indivíduos da classe média não se considerava em revolta contra o rei, crendo somente haverem expulso um mau governador e esperavam receber um melhor da corte do Rio de Janeiro". Razão pela qual os membros da junta só pronunciavam "a palavra república em voz baixa e só discorrem sobre a doutrina dos direitos do homem com os iniciados", o que equivalia à confissão de que "ela não seria compreendida pela canalha”. Refere o francês que sugerindo a seu amigo, o padre João Ribeiro, que publicasse uma gazeta para doutriná-la, lhe respondera sonsamente: "Convém deixá-los neste erro". "O povo não tomava parte alguma na insurreição", não se vendo nele "nenhum entusiasmo, nenhum transporte”. E lembrando-se das jornadas revolucionárias de Paris, anotava: "Que diferença de ardor entre esta populaça e a nossa". Ainda segundo Tollenare, "o povo [...] tinha-se armado sem saber para quê e podia facilmente ser dirigido contra os rebeldes", caso as autoridades régias tivessem realmente tentado controlar a situação. ${ }^{5} \mathrm{Na}$ Paraíba, "a novidade arrastou mecanicamente, sem indício de oposição em toda a provín- 
cia”; no Rio Grande, "o povo permanecia inerte espectador" ${ }^{6} \mathrm{O}$ adesismo da administração era geral, donde não ter havido substituições nos altos cargos, exceto a intendência da Marinha, sequer entre os comandos da milícia. $^{7}$

A contenda entre pedreiros-livres fluminenses e pernambucanos veio à tona desde os primeiros dias de Dezessete, quando ficou claro que os adeptos da monarquia constitucional haviam sido cuidadosamente mantidos à margem da conspiração, precipitada pelas medidas de repressão do governo exigidas pelos oficiais reinóis, vários dos quais eram maçons ou simpatizantes (se é que não o próprio governador Caetano Pinto de Miranda Montenegro), ao se darem conta das intençóes republicanas do grupo de Domingos José Martins. Vitoriosa a insurreição, cumpria definir o programa do novo regime. Quando a junta governativa, formada às pressas por um colégio de dezessete eleitores escolhidos nas camadas urbanas, debateu o assunto, o representante dos letrados, José Luís de Mendonça, que combinara a manobra com Antônio Carlos Ribeiro de Andrada, propôs que se abrissem negociações com a Corte do Rio, reivindicando a redução de impostos e o estabelecimento de limites ao poder dos governadores. A proposta foi repudiada por Domingos José Martins, que dispunha do apoio dos oficiais da terra, sobretudo do capitão Pedro da Silva Pedroso, o qual "quis atravessar com a espada e matar a José Luís de Mendonça, porque este fizera a moção de se estabelecer um reino constitucional em lugar de uma república". ${ }^{8}$ Mendonça ficou a partir daí em posição isolada no governo revolucionário.

Mesmo o representante da agricultura, Manoel Correia de Araújo, que simpatizava com sua posição, eximiu-se de apoiá-la, ao passo que os demais membros, o padre João Ribeiro, representante do clero, e o capitão Domingos Teotônio Jorge, do Exército, eram, como Domingos José Martins, notórios por seus sentimentos "monarcômacos". ${ }^{9}$ Os republicanos dispunham, portanto, da maioria no seio da junta, sem falar em que a minoria constitucional achava-se intimidada pelos militares. Tollenare, que conheceu Mendonça de perto, traçou o perfil de um reformista típico: próspero na sua atividade profissional, gozava do respeito geral e, em particular, do das "pessoas de consideração". Nas suas conversas com o francês, Mendonça, 
que ignorara a conspiração, não punha em causa o regime monárquico, limitando suas críticas aos abusos da administração colonial, críticas que eram gerais e que, advertia Tollenare, eram erroneamente confundidas com "desejos revolucionários", embora pudessem ser muitas vezes o prelúdio das revoluções, como acontecera na França. ${ }^{10}$

Antônio Carlos Ribeiro de Andrade, cuja nomeação para ouvidor de Olinda teria sido planejada pelos mações fluminenses para colocar a maçonaria da terra sob a tutela do Rio, ${ }^{11}$ ainda tentou salvar a proposta de negociação com a Coroa, e malgrado considerá-la comprometida pela inabilidade de Mendonça, fez idêntica gestão, mas em caráter particular, junto a Domingos José Martins e ao padre João Ribeiro. Ambos o desencorajaram, respondendo-lhe dissimuladamente que "a lembrança era boa e poderia ter efeito a não ser a imprudência do dito José Luis, mas que agora já não tinha mais lugar porque nem a tropa nem o povo o queriam e quem lha propusesse morreria necessariamente, o que esperavam que, ele, respondente, não fizesse". ${ }^{12}$ Antônio Carlos ainda contactou outro dos próhomens que, como ele, haviam permanecido na ignorância da insurreição, o coronel Suassuna, que, ao saber do seis de março, partira para o Recife com o seu séquito de milicianos e de escravos aos gritos de 'Viva El-Rei', tornando-se suspeito a Domingos José Martins ${ }^{13}$.

Conhecendo "o quanto era poderosa a família do dito capitão-mor pela extensão de suas alianças e parentescos”, Antônio Carlos sondou-o sobre os rumos do movimento, concordando ambos em que "os homens de qualidade estavam arruinados se não ajuntarem os seus esforços para destruir uma cabala de malfeitores". ${ }^{14}$ Não se pode negar que Antônio Carlos e muitos outros julgavam terem mais a perder com a república do que com a monarquia constitucional, donde não haver sido de todo insincera sua alegação perante a Alçada, de que não poderia aderir

sinceramente a uma ordem de coisas que, roubando-lhe a paz, o arremessava às vagas de uma oclocracia tempestuosa, e privando-o de um lugar honroso e de lucro, o reduzia a humilde cliente de demagogos, a maior parte tirados do pó e sem mérito? Como não odiaria antes e trabalharia com afinco para destruir um sistema que, derrubando-o da ordem da nobreza a que pertencia, o punha a par da canalha e ralé de todas as cores e lhe segava em flor as mais bem fundadas esperanças de ulterior avanço e de mores dignidades? ${ }^{15}$ 
Parece evidente que o santista não argumentava apenas para ver-se livre do régio castigo. Que o caráter republicano assumido pelo movimento o fazia realmente temer as conseqüências pessoais, sobretudo se fora enviado ao Recife para preparar uma insurreição monárquico-constitucionalista, vê-se da carta ao irmão em que, em abril de 1817, lamentava a adversidade da sorte, que o deixara agora "sem meios certos de subsistência" devido à extinção das ouvidorias pelo governo revolucionário. ${ }^{16}$ Às manobras de Antônio Carlos, devia estar associado um projeto de "contra-revolução para pedirem a Sua Majestade que desse nova Constituição", à maneira dos "rebeldes constitucionais” espanhóis, projeto que a alçada encontrará entre os papéis de outro maçon, o deão da Sé de Olinda, o Dr. Bernardo Luís Ferreira Portugal. ${ }^{17}$

A Antônio Carlos, Suassuna teria prometido aliciar apoios no sul da capitania, ficando a cargo do Andrada contactar um setor da tropa de linha. ${ }^{18}$ Enviado pela junta para barrar a marcha do exército realista da Bahia, Suassuna procurou efetivamente entabular negociações com o general Congominho, ${ }^{19}$ contando seguramente com a adesão de oficiais maçons de tendência constitucionalista que o assessoravam. ${ }^{20}$ É plausível que tais contatos tenham chegado ao conhecimento do governo provisório, incitando-o a despachar para o sul outra tropa sob o comando de Domingos José Martins, o que significava que este, como membro da junta, chamaria a si o comando. Suassuna aparentemente resistiu, com o que se adotou a solução, tão criticada por Muniz Tavares, ${ }^{21}$ de manter separadas as duas forças, que foram assim mais facilmente batidas pelo exército realista.

Ao proclamar a forma republicana, Dezessete redundava numa derrota da maçonaria portuguesa e fluminense. A insurreição não foi um fenômeno isolado, pois no Rio, na Bahia e em Lisboa as conspirações maçônicas estavam na ordem do dia: em maio de 1817 o governo do Reino descobria a conjura de Gomes Freire de Andrade, a ser deflagrada em agosto, a qual hesitava entre manter o Bragança no trono ou substituí-lo pelo ramo Cadaval. Em Salvador, chegou-se a cogitar da criação de cinco reinos no Brasil, segundo a alegação do padre João Ribeiro, autor da proclamação aos baianos feita pelo governo do Recife, que envolveu inclusive o conde dos Arcos, governador da Bahia, acusado de "pretender trair D. João VI", 
destruindo "um trono odiado para substituir-lhe milhares de tronos ainda mais aborrecíveis", enquanto "o povo, o desgraçado povo, era condenado a satisfazer o orgulho e pretensões de um bando de aristocratas ávidos de sangue, insaciáveis de pompas e grandezas vãs e jamais satisfeitos com as humilhações dos seus escravos". ${ }^{22}$ Mas não é menos verdade que a revolução pernambucana tomou diferente caminho, para desapontamento dos pedreiros-livres do Reino e da Corte.

Informava Carlos de Alvear, o enviado argentino ao Rio, o plano da maçonaria consistira em compelir D. João VI a convocar as Cortes portuguesas e jurar uma Constituição, na linha, como se vê, do que Gomes Freire de Andrade planejava no Reino e do que as lojas do Porto executarão com êxito em 1820. Ocorrera que em Pernambuco os mações republicanos "não só se haviam antecipado mas não haviam feito a revolução conforme o combinado": "os mações americanos trataram de enganar os europeus com a idéia de constituição [monárquica], mas seu verdadeiro plano foi e é de constituir-se em república”. O informante de Alvear, visivelmente português, aduzia que "se os pernambucanos houvessem seguido debaixo destes princípios, a coisa [o levante no Rio] se levaria a cabo". Diante do fato consumado no Recife, a maçonaria fluminense se havia dividido, "uns a favor, que são geralmente brasileiros, e outros em contra, que são os europeus e muitos brasileiros". ${ }^{23} \mathrm{O}$ cônsul francês em Lisboa oferecia a mesma versão: a república fora proclamada mas "diferentes pessoas pretendem aqui que o objetivo deste movimento era de forçar a família reinante a conceder uma nova constituição e a adotar o sistema representativo". ${ }^{24}$

Os relatos de informantes da Coroa precisam os contornos da conjura fluminense em prol da reforma das instituições monárquicas. Sob a chefia do barão de São Lourenço, alvo de graves acusações de peculato, um daqueles "plebeus enricados" a quem D. João nobilitara após promovê-lo de arrecadador de rendas no Ceará a tesoureiro-mor do Reino, ${ }^{25}$ dela participariam, entre outros, "três [comerciantes] ingleses dos mais poderosos desta cidade”, certo frade pernambucano, José de São Jacinto Mavignier, pregador da Capela Real, outro pernambucano, José Fernandes Gama, tio de Bernardo José da Gama, ouvidor de Sabará (ambos destinados a desempenhar papel de relevo na política da província), seu aliado desde então, 
Ludgero da Paz, contador da fazenda em Pernambuco, dois mercadores portugueses do Rio, um deles com correspondentes no Recife, e o agente de Bento José da Costa, importante homem de negócios daquela praça. Que se trata do grupo contactado por Alvear deduz-se da referência ao projeto constitucional segundo o qual El-Rei teria seus poderes reduzidos, e da referência a que os sectários "têm dado urros por ver não terem conseguido o seu plano" na esteira da insurreição pernambucana. ${ }^{26}$ Ora, Bernardo José da Gama e José Fernandes serão precisamente os articuladores da deposição da junta de Gervásio Pires Ferreira em 1822, o qual, devido à sua participação em Dezessete, era acusado de segundas intenções republicanas.

Sob a influência inglesa ou francesa, a maçonaria lusitana nunca tivera veleidades republicanas ou democráticas, para o que contribuíra incisivamente sua composição, caracterizada pela preponderância de militares e sacerdotes. "Muitos desses oficiais do Exército e da Marinha — já que era mínimo o número de sargentos e outros inferiores - pertenciam à nobreza, até mesmo à alta nobreza, ainda o núcleo social de base da instituição militar". Se o comércio, a magistratura, o funcionalismo público, as profissões liberais também se faziam representar, sua participação agregada não ia a mais de 30\%. "Ao contrário do que se passava em França, a maçonaria portuguesa discriminava em termos sociais, surgindo como uma união entre nobreza, clero e burguesia e não como uma sociedade cem por cento democrática, a todos aberta”. ${ }^{27}$ Mesmo durante a ocupação francesa, ela continuou fiel aos Braganças, embora começasse "a insistir-se cada vez mais na legitimidade do poder político, única a que o maçon era obrigado, e a contestar-se, cada vez mais também, a legitimidade do poder político dos Estados absolutistas despóticos". "Sem nunca atingir a instituição monárquica nem a figura do Príncipe governante — pelo menos até 1820 — grande número de maçons passou a defender uma fórmula de governo representativo que 'restabelecesse' a legitimidade política', tendência que, aliás, se acentuará a partir do fracasso da conjura de Gomes Freire. ${ }^{28}$ Abalada pelo fim do monopólio colonial, a burguesia mercantil convertia-se à idéia de constitucionalizar a monarquia como única maneira de garantir a defesa dos seus interesses em face do predomínio comercial e militar da Grã-Bretanha e à indiferença da Corte do Rio pelas dificuldades domésticas de Portugal. 
O objetivo da revolução do Porto (1820) e do nacionalismo antibritânico e anti-brasileiro que a inspirou será exatamente o de regenerar a monarquia, opção que "tinha menores custos políticos, indo ao encontro dos mais importantes interesses em jogo". ${ }^{29}$

O dissenso original de Dezessete insinuou-se na sua própria justificação política. Por um lado, o governo provisório invocou o descumprimento pelos Braganças do pretendido pacto com a capitania, segundo o mito constitucional para quem a restauração do domínio português no século XVII tivera a contrapartida de isenções de natureza fiscal e administrativa por parte da Coroa. "A idéia [escreverá o desembargador da Alçada] que os rebeldes fizeram ter aos seus chamados patrícios, ignorantes da história, [foi a] de que esta terra, sendo conquistada pelos seus [ante]passados aos holandeses, ficou sendo propriedade sua e que a doaram a El Rei Nosso Senhor, debaixo de condições que ele não tem cumprido" ${ }^{30}$ Daí a autoproclamação de Dezessete como "segunda restauração de Pernambuco", fórmula consagrada nos impressos oficiais. ${ }^{31}$ Semelhante noção pressupunha que enquanto os colonos pernambucanos eram 'vassalos políticos', os das demais regiôes brasileiras eram apenas 'vassalos naturais'. Por outro lado, a carta pastoral do deão da Sé de Olinda, o dr. Portugal, que resume o alegado estatuto na linguagem do 'contrato social', aduzia ao argumento da ruptura do pacto entre Pernambuco e a Coroa o do próprio pacto constitutivo da nação portuguesa, vale dizer, as pretendidas leis das Cortes de Lamego ${ }^{32}$, o que conota uma concepção que, ao invés do regionalismo da anterior, era coextensiva ao Brasil e ao Reino Unido.

A monarquia constitucional tinha pressuposto unitário, mas a república tinha-o provincial ou regional, de vez que o descompasso assinalado por Armitage entre as aspirações políticas do Nordeste e as do Centro-Sul inviabilizava a extensão do sistema republicano a todo o Brasil. Ao imporse à alternativa de monarquia constitucional, a república de Dezessete tinha de optar por uma base provincial ou regional. O único texto que se conhece a respeito é a carta do padre João Ribeiro ao governo provisório da Paraíba, de 31 de março de 1817. O sacerdote era categórico: "Pernambuco, [incluindo Alagoas, então comarca pernambucana], Paraíba, Rio Grande e Ceará devem formar uma só república”, pois “estas províncias estão tão 
compenetradas e ligadas em identidade de interesses e relações, que não se podem separar", tanto mais que haveria escassez de quadros dirigentes, ao menos "enquanto não se propagam as luzes". ${ }^{33} \mathrm{~A}$ idéia de que o Nordeste oriental constituía uma latente entidade estatal já se encontrava formulada nas diretrizes constitucionais de 1799, alegadamente redigidas por Arruda da Câmara, João Ribeiro e José Fernandes Portugal, as quais aludiam às "províncias federadas desde Alagoas até as extremidades ao norte do Ceará" . ${ }^{34}$

Esta opinião, a que o padre permanecia fiel dezoito anos depois, não era, porém, consensual na junta recifense, segundo ele mesmo reconhecia. ${ }^{35}$ O ex-revolucionário Muniz Tavares referirá que o êxito inicial da revolução na Paraíba e no Rio Grande do Norte havia encorajado os patriotas a estenderem "suas vistas [...] ao bem ser de todo o Brasil". Ocorria apenas que "as províncias do norte [estando] mais distantes do sopro empestado da Corte seriam as mais solícitas em responder ao grito da liberdade", ao passo que, no longo prazo, "as do sul seguiriam [...] o mesmíssimo destino". Caso não o fizessem, uma confederação do norte nada teria a temer do Rio de Janeiro. ${ }^{36}$ João Ribeiro escrevia à junta paraibana para dissipar a suspeita de que o projeto regionalista visasse a "engrandecer Pernambuco, sujeitando-lhe as outras províncias como antigamente", propondo desde logo que a capital da república fosse construída, "como condição essencial", no interior da Paraíba, a trinta ou quarenta léguas do litoral. ${ }^{37}$

A articulação entre ambas capitanias tornara-se premente em decorrência das medidas econômicas tomadas pelo governo paraibano, abolindo impostos, reduzindo os direitos alfandegários à metade e igualando-os entre as nações, diminuindo em $50 \%$ o tributo sobre a exportação de algodão e monopolizando o pau-brasil, providências todas que eram de molde a comprometer o erário republicano no momento em que teria de arcar com as despesas da guerra com o Rio. João Ribeiro via na redução das tarifas o propósito de atrair para a capital paraibana o comércio exterior, em detrimento do Recife. Ora, "os hábitos e costumes dos seus habitantes são tão semelhantes, que as leis que convierem a uma, convirão necessariamente à outra província. O terreno da beira-mar de ambas as províncias dão as mesmas produções, o médio, as mesmas, o do interior, as mesmas, que são gados e algodôes". A Paraíba tinha todo direito em procurar atrair os nego- 
ciantes estrangeiros, mas devia adiar a iniciativa para quando a república estivesse consolidada, concentrando de imediato seus esforços na própria defesa, em vista da vulnerabilidade das cidades litorâneas ao ataque externo. ${ }^{38}$ Asseverou-se que "a revolução de 1817 não foi separatista mas pretendia a independência e a integridade do então Reino Unido do Brasil". ${ }^{39}$ Separatista ela evidentemente não foi, pois o separatismo pressupõe a constituição prévia da nação e, esta, em 1817, não existia, a monarquia portuguesa sendo a forma vigente do Estado, de que o Rio de Janeiro era a capital. A acusação de separatismo de Dezessete, seja pelos que a formulam, seja pelos que a rejeitam, é um pseudoproblema. Mesmo Varnhagen, cuja antipatia pelo movimento é conhecida, absteve-se de caracterizá-lo como separatista, cônscio provavelmente de que incorreria em anacronismo, pois o que existia então ainda não era o 'Reino Unido do Brasil', como inadvertentemente se afirma, mas o 'Reino Unido de Portugal, Brasil e Algarves', proclamado em 1815. Ao complicar a articulação regional com o processo emancipador no Centro-Sul, Dezessete e, a fortiori, Vinte e Quatro criaram a suspeita de separatismo sob a qual viveu Pernambuco ao longo do Segundo Reinado, suspeita encampada pela historiografia do Segundo Reinado, ao reivindicar para os conservadores flumi-nenses o beau rôle de construtores da nacionalidade contra os particularismos regionais. Como observava Horace Say, o Brasil àquela altura era apenas "a designação genérica das possessões portuguesas na América do sul”, não existindo "por assim dizer unidade brasileira”, ${ }^{40}$ donde a preferência da língua inglesa pelo plural 'the Brazils'. Se em Dezessete não havia unidade brasileira, em Vinte e Quatro ela não saíra do papel do projeto discutido pela dissolvida Constituinte e da Carta outorgada pelo Imperador. Como não se cansava de lembrar frei Caneca, o Brasil estava independente mas não estava constituido.

Mas se nosso ciclo revolucionário não pode ser reputado separatista, cabe duvidar de que ele considerasse a unidade do Brasil como a prioridade das prioridades ou que sequer estivesse disposto a sacrificar os princípios liberais no altar do 'grande Império', isto é da entidade unitária que abrangesse a massa continental entre o Amazonas e o Prata. Nossa tradição provincial não visava apenas emancipar-nos de Portugal, mas também, e com não menor empenho, preservar a autonomia local no âmbito do Esta- 
do que surgisse do colapso da monarquia absoluta, qualquer que fosse a forma que tomasse, seja a de um Império constitucional luso-brasileiro, como desejavam as Cortes de Lisboa, seja a de uma monarquia liberal no âmbito da antiga América portuguesa; e na impossibilidade de conseguir um sistema autônomo, fazer inferno à parte. O que Tobias Monteiro observou com razão, mas sem compreensão, a respeito de frei Caneca, poderia ser escrito acerca de um bom número de protagonistas de nossas 'revoluções libertárias': ele "não via na união nacional e na integridade do Brasil o problema máximo da Independência”. ${ }^{41}$ Para aquela parcela da geração de Dezessete que se sentou depois na junta de Gervásio Pires Ferreira e no governo da Confederação do Equador, a liberdade pernambucana primava sobre a unidade do Brasil.

Sua grande prioridade era a construção de um Estado de direito descentralizado, objetivo tão válido quanto o outro, e ambos na dependência de julgamentos políticos de valor. Como indica o fato de que resistiu à ação de instituições supralocais, como a Maçonaria e o funcionalismo da Coroa, que buscavam integrá-lo em correntes mais largas, nosso particularismo não foi epidérmico, embora insuficientemente articulado em termos de doutrina constitucional. Nada lhe poderia ser mais alheio do que o projeto de criar um grande Império, o qual, quando as Cortes de Lisboa liquidarem a concepção dual do Reino Unido, tornar-se-á o blueprint da fórmula fluminense. Ademais, nossa posição geopolítica, à margem da massa continental brasileira, privara-nos de sentimento sertanista, que não se podia esperar em capitania que havia trocado os 'sertóes de dentro' pelos 'sertóes de fora' e cuja população achava-se ainda esmagadoramente concentrada na zona da mata.

No tocante a Dezessete, é indispensável distinguir seus objetivos, das suas repercussóes na América portuguesa. Os temores de contágio insurrecional denotavam apenas as preocupações de quem os exprimia, não qualquer propósito unionista da parte do governo revolucionário. Assim que deve ser lida a previsão do abade du Pradt segundo a qual "se a independência de Pernambuco prevalecer, a do Brasil será a consequiência necessária, o que completará a independência de toda a América do Sul”. ${ }^{42}$ Ela não significa que Pernambuco promoveria a independência do Brasil, apenas 
que o resto do Brasil tenderia a fazer por sua própria conta o que Pernambuco fizera, não necessariamente em acordo com este. Por outro lado, quando o encarregado de negócios britânico no Rio expressava a mesma apreensão, como via-de-regra a correspondência diplomática do período, o que o preocupava era a adesão de todo o Norte ao movimento, não a do Centro-Sul. ${ }^{43}$ Alvear reporta-se à Bahia, Pará e Maranhão como os alvos dos rebeldes, não ao Centro-Sul. ${ }^{44}$ Era natural que, em face do que ocorria na América espanhola e da inércia da Coroa lusitana, Dezessete fosse visto como a onda do futuro, embora dentro em pouco o secretário do exterior britânico, Lord Castlereagh, se tranqüilizasse ao constatar que a insurreição tivera "menor alcance do que a princípio se supôs". ${ }^{45}$ Sabendo-se isolada no seu republicanismo, a junta revolucionária do Recife não devia alimentar ilusóes sobre o apoio do Sudeste, o qual se, na melhor das hipóteses, também se revoltasse, fá-lo-ia sob a forma da monarquia constitucional pregada pelos mações fluminenses, motivo pelo qual não se teria mostrado menos hostil a Dezessete do que o governo de D. João VI. Se o 6 de março foi um êxito da maçonaria republicana, não havia por que procurar a adesão do Centro-Sul, que só poderia comprometer a natureza do novo regime.

É sintomático que as missões pré-revolucionárias enviadas do Recife tenham-se limitado à Bahia, ao Ceará, ao Rio Grande do Norte e à Paraíba, embora Domingos Teotônio Jorge também tivesse viajado ao Rio. Que houve contatos com os mações fluminenses, já o vimos, como vimos também seu desapontamento com o seis de março. Uma vez vitoriosos, os republicanos contentaram-se em dirigir proclamações às províncias do Nordeste que ainda não se haviam pronunciado, abstendo-se de conclamar o Rio e as províncias do Centro-Sul. As alusões ao Brasil insertas nos manifestos à Bahia eram recurso retórico para encorajar a tibieza dos baianos, da mesma maneira como a propaganda revolucionária apregoava, para consumo interno e externo, que o movimento contaria com o apoio de outras regiōes. Quando o enviado da junta, Cabugá, assegurava em Washington que a revolução estender-se-ia a toda a colônia, o fazia para os fins óbvios de obter o auxílio norte-americano, da mesma maneira pela qual, no objetivo de impressionar a população, prometia-se a Pernambuco que o Brasil estava a ponto de aderir, manobra que não escapou ao dicionarista 
Morais. ${ }^{46}$ Obviamente, do ponto de vista dos chefes republicanos, a conflagração do Centro-Sul lhes traria ao menos a vantagem estratégica de retardar a reação militar do Rio, mas eles não acreditaram em tal possibilidade, embora tivessem de dar publicamente a impressão de contarem com ela.

Julgava Oliveira Lima que em Dezessete a influência da Revolução francesa fora maior que a da Revolução americana. Por uma questão de mimetismo e de intoxicação ideológica, Dezessete utilizou a cenografia e o gestuário da Grande Revolução, cuja dramaticidade era mais apta a empolgar imaginaçôes brasileiras do que a Revolução americana. Mas se o governo provisório do Recife possuía exemplares das constituiçōes de 1791, 1793 e 1795, mostrando preferência pela mais razoável delas, a termidoriana, ${ }^{47}$ ele dispunha, por outro lado, do "livro das constituições" que Benjamin Franklin "compusera para as colônias da América inglesa" ${ }^{48} \mathrm{~A}$ realidade é que a experiência norte-americana oferecia figurino adequado à tradição autonomista, o que não era o caso da Revolução francesa, cuja concepção unitária do Estado buscava precisamente liquidar os particularismos regionais, identificados com o poder da aristocracia mediante o sistema de departamentos. Nos primeiros dias do movimento, o cônsul britânico informava que o regime se pautaria pelo "modelo [federal] dos Estados Unidos da América”. ${ }^{49}$ E em Washington, declarava o Cabugá que a constituição "deve ser modelada pela dos Estados Unidos, com aquelas alterações ou modificações análogas aos costumes do país". 50 "O êxito da federação americana faz virar muitas cabeças", sobretudo em vista da "economia de despesas com uma Corte". ${ }^{51}$

Oliveira Lima via influência da fórmula termidoriana na composição da junta revolucionária por cinco diretores, com o propósito de "manter a supremacia do poder civil" em face das tentaçōes de um 18 Brumário, ${ }^{52}$ o que, contudo, não impedira Bonaparte de tomar o poder. Na realidade, o principal objetivo na formação do governo de Dezessete consistira em dar base social amplamente representativa a uma comissão eleita por dezessete indivíduos, escolhidos a dedo, como ele se apressava em assinalar na sua proclamação de 9 de março e no manifesto que ficou conhecido pelo galicismo de 'Preciso', a primeira ainda usando a expressão "ordens do Es- 
tado", o segundo, já recorrendo à palavra "classes". Caberia salientar ademais que a tradição republicana sempre estivera associada aos regimes de tipo colegial, de modo a frisar sua diferença com o despotismo dos sistemas monárquicos.

Por fim, afirma Oliveira Lima que o exemplo de Termidor explicaria que os chefes de Dezessete se tivessem esquivado "a uma Constituinte, pelo menos imediata”. Na verdade, as razóes para tal foram bem mais complexas. $\mathrm{O}$ novo regime não desfrutou de tempo suficiente para deflagrar o processo constituinte, em conseqüência da rapidez da reação da Coroa. Nos Estados Unidos, ele levara nada menos de treze anos, que tantos são os que contam entre o primeiro Congresso Continental (1774) e a Constituição federal de 1787. Os Artigos de Confederação, adotados em 1777 para entrarem em vigor quatro anos depois, previam uma coordenação frouxa das treze colônias no exercício dos poderes anteriormente exercidos pela Coroa britânica em matéria de defesa, relações exteriores, moeda e política indigenista. Por sua vez, a ratificação da Constituição federal pelas ex-colônias teve de esperar dois anos. À falta de tempo, acresce que o governo do Recife não dispunha de instituições preexistentes que se prestassem a canalizar a elaboração constitucional, como as assembléias coloniais que na América inglesa serviram de modelo às assembléias revolucionárias que prepararam as constituiçôes estaduais, embora elas preferissem por vezes recorrer à legislação ordinária ou mesmo manter as cartas outorgadas pelo governo inglês quando da fundação das colônias. Só em 1780, no Massachusetts, surgiu a primeira Constituição, no sentido moderno da palavra de estatuto escrito e qualitativamente superior à lei ordinária.

Evidentemente, a experiência norte-americana teria permitido a Dezessete queimar etapas. Muniz Tavares sustentará que, a exemplo das colônias norte-americanas, a junta do Recife deveria ter convocado imediatamente um corpo constituinte e legislativo à maneira do Congresso continental, que estabelecesse "uma liga federal" para prover à segurança externa, embora lamentando que "a péssima educação portuguesa não habilitasse os brasileiros ao desenvolvimento rápido da ciência política" ${ }^{53} \mathrm{~A}$ tal opção corresponderia provavelmente o projeto, cujo texto ignora-se, encomendado a Manuel José Pereira Caldas, a quem confidenciara o inter- 
locutor a esperança de que ele viesse a ser o Benjamin Franklin de Dezessete, projeto cuja existência o próprio Caldas reconheceu perante a Alçada, aduzindo haver sido posto de lado em favor do redigido por "outro conselheiro", Antônio Carlos Ribeiro de Andrade. ${ }^{54}$ Embora não tivesse tido tempo para convocar o Congresso regional, é inegável que o governo do Recife visava à criação de instituições confederais. Na sua já citada carta ao governo da Paraíba, o padre João Ribeiro salientava, por exemplo, que a questão do que fazer com o antigo regime municipal herdado da colonização deveria ser resolvido pelo que chamava "o Congresso geral" ${ }^{55}$ Mas a idéia de uma convenção que elaborasse uma carta na linha dos 'Artigos da Confederação' foi deixada para depois, em favor do estabelecimento de Constituição pernambucana, a ser aprovada por uma assembléia provincial tão logo se verificasse a adesão das comarcas de Alagoas, do sertão e do São Francisco, como previa a 'lei orgânica', que deveria vigir até lá e cujo texto, endossado pelo governo do Recife a 29 de março de 1817, fora elaborado por Antônio Carlos com vistas a ser submetido à aprovação das Câmaras municipais.

Caso a constituinte pernambucana não houvesse sido convocada dentro de um ano ou na hipótese de que a Constituição não ficasse concluída no triênio seguinte, o governo provisório seria automaticamente extinto, devolvendo-se ao povo o exercício da soberania, "para o delegar a quem melhor cumpra os fins da sua delegação" (art. 28). Até a adoção da carta, o governo provisório enfeixaria os poderes executivo e legislativo (art. 1). No exercício das competências legislativas, somar-se-ia ao governo provisório um conselho permanente de seis membros, escolhidos pelas câmaras municipais entre "os patriotas de maior probidade e luzes em matéria de administração", desde que não tivessem parentesco até o segundo grau canônico, dos dois secretários de Estados (assuntos internos e externos), do Inspetor do Erário e do bispo, que estando Olinda sede vacante, seria substituído pelo deão. O governo e conselho decidiria por maioria de votos, suas leis sendo assinadas apenas pelos membros do primeiro, que também desempenhariam em caráter rotativo e semanal a presidência do colegiado. $\mathrm{O}$ governo poderia ouvir o conselho em matéria de competência executiva. Por crime de responsabilidade, os governadores só poderiam ser 
processados ao fim da sua gestão, mas os secretários de Estado o seriam imediatamente (arts. 2-11).

Enquanto este sistema misto vigisse, a fazenda pública seria gerida por um Inspetor do Erário, diretamente dependente do governo (art.12). A administração da justiça (arts.13-20) seria composta, em primeira instância, dos dois juízes ordinários (crime e cível) já existentes em cada câmara municipal. De suas sentenças, recorrer-se-ia ao Colégio Supremo de Justiça. Ficavam extintos os cargos de ouvidor, cuja jurisdição retornaria aos juízes ordinários, que seriam inquiridos anualmente pelo Colégio de Justiça. Este seria composto de cinco membros vitalícios, só removíveis por sentença. Para os crimes militares, haveria órgão específico. As leis até então em vigor continuariam a sê-lo, a menos que derrogadas ou definitivamente substituídas por um "código nacional e apropriado às nossas circunstâncias e precisóes" (art.21). Era preservado o antigo sistema municipal (art. 22). O catolicismo era a religião do Estado e seus sacerdotes seriam pagos pelo governo, mas haveria tolerância das dissidências religiosas (arts. 23-4). A liberdade de imprensa ficava garantida, prevendo-se crime de responsabilidade (art. 25). Os reinóis estabelecidos na terra que se naturalizassem e dessem provas de adesão ao novo regime teriam acesso aos empregos públicos (art. 26). O mesmo privilégio se estenderia aos estrangeiros de "comunhão cristã" que fossem naturalizados por ato do governo (art. 27). ${ }^{56}$

Segundo Muniz Tavares, a elaboração e aprovação da lei orgânica requereram "longo tempo [...], de maneira que, quando foi apresentado, já era mui diversa a face dos negócios pela variação das províncias limítrofes". ${ }^{57}$ Os municípios deveriam com brevidade "convocar o povo de todas as classes para votarem sobre o dito projeto", ato que deveria ser "o mais solene possível" e ter o concurso do "povo quase todo, pois lhe interessa conhecer o como hão-de ser governados". Juntamente ao texto, seguia o de uma lei de anistia, a ser comunicada à população. ${ }^{58}$ As assembléias municipais chegaram a ser realizadas no Recife, em Olinda e em Igaraçu, sendo, porém, suspensas pelo governo provisório, quando "os adversários da causa liberal valeram-se do mesmo projeto para mais desvairarem a opinião pública”, mal interpretando o artigo relativo à liberdade de culto e à igualdade de direito. "Valendo-se da tendência dos devotos, clamavam os perversos com 
estudada hipocrisia que o intento dos patriotas era destruir a religião e dar liberdade aos escravos". ${ }^{59} \mathrm{Na}$ verdade, o projeto de lei orgânica não falava em igualdade de direitos; e segundo outro contemporâneo, Dias Martins, o descontentamento manifestado nas câmaras disse respeito exclusivamente à liberdade religiosa, ${ }^{60}$ embora se deva aduzir a indignação das oligarquias municipais com as instruções no sentido de que "o povo de todas as classes" fosse também chamado a se pronunciar.

Tinha razão Muniz Tavares quando criticava a consulta às Câmaras por isolar "os interesses recíprocos" e por não oferecer "aquela unidade que constitui a máxima força da lei" ${ }^{61}$ As razōes do recurso ao antigo sistema camerário, deu-as João Ribeiro. Como a junta paraibana houvesse abolido as Câmaras, o padre opinava tratar-se de "um absurdo em toda a extensão da palavra”, pois um governo não poderia constituir-se sem ser ou por manifestação da "maioria do povo por si própria, ou pelo órgão das Câmaras, que representam o povo nas diversas seçôes ou municipalidades". "Se vós não tivésseis feito isto por mera ignorância, deveríeis ter sido apunhalados pelo povo da Paraíba no dia em que promulgastes tão horrível lei, que os triunviros de Roma não se atreveriam a promulgar". ${ }^{62}$ Por deficiente que fosse, o antigo sistema municipal constituía a única forma de representação, não se podendo destruí-lo antes de se criarem outras formas "quando se fizer o Congresso geral e se fizer a constituição [federal], em que ou ficarão as câmaras ou coisa idêntica, ainda que tenha outro nome". ${ }^{63}$

Daí que o projeto de lei orgânica houvesse taxativamente previsto que "a administração das câmaras ou municipalidades continua no pé antigo" (art. 22), o que era, aliás, um understatement, pois, de fato, o poder local saía fortalecido mediante a extinção dos antigos ouvidores e corregedores, cujas funções eram cometidas aos juízes ordinários das Câmaras (art. 14). O nativismo pernambucano ajustava suas contas mais que seculares com a justiça régia. A alternativa aventada por Muniz Tavares teria de ser a eleição de assembléias provinciais, à moda americana, o que teria evitado que a contra-revolução instrumentalizasse as Câmaras, bloqueando o debate da lei orgânica. ${ }^{64}$ A tentativa de pôr vinho novo em velhos odres estava fadada ao fracasso. $\mathrm{O}$ antigo sistema municipal não era autenticamente representativo, sendo, por isso mesmo, necessariamente conservador, como com- 
preenderá muito bem frei Caneca em 1824 ao opor-se à participação das Câmaras no processo constituinte deflagrado pela Corte do Rio de Janeiro.

O próprio Tollenare, a cuja opinião Oliveira Lima adere, explicou as hesitações do governo revolucionário em matéria constitucional pelo fato de que não sabia como incorporar os homens de cor livres ao mecanismo de representação. ${ }^{65}$ As Constituições francesas de 1791, 1793 e 1795 haviam adotado, com variantes, um sistema eleitoral relativamente amplo, que mesmo a Constituição termidoriana, com toda sua obsessão pela manutenção da ordem burguesa, não ousou abolir. ${ }^{66}$ Segundo Tollenare, a preferência do governo de Dezessete ia para um sistema eleitoral com base na propriedade fundiária, ao mesmo tempo em que descreve o padre João Ribeiro, de cuja amizade também privou, "arrastado pela leitura das obras de Condorcet". ${ }^{67}$ Referência preciosa que dá uma pista acerca das tendências do principal ideólogo de Dezessete, que, como tal, desfrutava de grande ascendência intelectual e moral sobre seus pares. Na Revolução francesa, Condorcet encarnara a tendência, oposta à dos herdeiros de Rousseau, a um tipo de discurso que mergulhava suas raízes na fisiocracia e nos iluministas escoceses. Discípulo de Turgot, Condorcet batera-se antes da Revolução por uma monarquia reformada através de uma administração racional, que através da aplicação à política e à economia dos métodos matemáticos, garantisse um autêntico sistema de representação dos interesses sociais. ${ }^{68}$ A chave do sistema devia residir, segundo Turgot, não na igualdade política, que será, sob a forma do cidadão ativo em oposição ao cidadão passivo, titular de direitos civis mas não políticos, o princípio adotado pelas Constituições revolucionárias, mas no modelo do cidadão-proprietário rural, que tinha um interesse vital em que o país fosse bem governado por serem, nas palavras mesmas de Condorcet, "os únicos cidadãos verdadeiros".

Era o corolário político da doutrina fisiocrática. Se a agricultura constituía a única atividade realmente criadora de riqueza, em torno dela é que se devia reconstruir o Estado. As demais classes eram estranhas à nação, o comércio pela sua vocação cosmopolita a buscar o lucro onde ele se encontrasse, e o artesanato pela precariedade do salário e pela falta de domicílio fixo que também os desenraizava, só a ligação permanente à terra propor- 
cionando garantia de integração social. Destarte "o interesse das diferentes classes na felicidade geral da sociedade está na razão inversa da facilidade que têm de mudar de pátria”. Cabe, porém, advertir contra o anacronismo de encarar semelhante teoria como conservadora em termos da França de meados do século XVIII, pois ao criar o imposto territorial ela buscava precisamente substituir a concepção tradicional de uma sociedade de ordens por uma classe de proprietários rurais que se distinguiam, por um lado, do povo, mas sobretudo, por outro, do clero, da nobreza e da alta burocracia. Às vésperas de 1789, não era ainda a igualdade política, mas o cidadão-proprietário que "constituía o horizonte natural da reflexão sobre os direitos políticos para aqueles que se tornarão os atores da Revolução". Se a Constituição de 1791 não adotou tal sistema é que ele se revelara minoritário, embora Sieyès ainda partisse dele para chegar a sua concepção de cidadania ativa. ${ }^{69}$

Daí, outra pista valiosa de Tollenare, julgar o padre João Ribeiro que "o governo popular não valeria de nada" ${ }^{70}$ Não nos apressemos, contudo, em chamá-lo de reacionário. A grande maioria dos filósofos pré-revolucionários que se bateram pelo Estado de direito tampouco pensavam em termos de igualdade política, por considerarem que as massas respondiam apenas às paixões e às necessidades, estando incapacitadas de acederem à reflexão. ${ }^{71}$ Ora, a situação de Dezessete era enormemente complicada pela existência da população servil. Havendo circulado nos dias iniciais do movimento o rumor da emancipação dos escravos, o governo provisório sentiu-se obrigado a negar que alimentasse tal propósito, embora se tratasse de "uma suspeita que o honra". Convencido da igualdade dos homens independentemente da cor, dizia-se, porém, persuadido de que o respeito da propriedade era a base da sociedade civil. "O governo não engana ninguém"; e "impelido destas duas forças, deseja uma emancipação [...] mas deseja-a lenta, regular e legal", mesmo se "o coração se lhe sangra ao ver tão longínqua uma época tão interessante, mas não a quer prepóstera” ${ }^{72}$ É óbvio que uma preferência fisiocrática por um sistema eleitoral baseado na propriedade da terra descartava de saída as veleidades abolicionistas, de vez que a Abolição pura e simples teria liquidado a existência daquela mesma classe em que o novo regime devia basear-se. 
Não é incongruente, como pode parecer à primeira vista, que uma revolução realizada por grupos urbanos se mostrasse tão sensível à propriedade da terra, de que dependia exclusivamente a exportação da capitania. Como escrevia um patriota de Alagoas, com o triunfo da República, "os céus se rasgarão em nosso abono, rasguemos gostosamente os nossos campos, que já os nossos suores não se perderão de vista pelas barras fora para abastecer tiranos e esfaimados monstros da ingratidão. Mugi alegres as vossas vacas e não esperdiceis os frutos que a terra tão liberalmente lança de seu seio". ${ }^{73} \mathrm{E}$ um revolucionário paraibano declarava que "a agricultura é uma das bases fundamentais que devem suster o todo desta obra admirável, a que tão felizmente temos dado princípio" ${ }^{74}$ Embora o padre João Ribeiro olhasse com sérias reservas as medidas econômicas da junta da Paraíba, congratulava-a entusiasticamente pelo decreto que removera "os gados para o interior, a bem da agricultura", certamente "ditado por algum anjo". ${ }^{75} \mathrm{O}$ pagamento dos juros das dívidas à extinta Companhia Geral de Pernambuco e Paraíba, abolida em 1780, foram perdoadas pelo governo do Recife desde que o principal fosse satisfeito no prazo de dois anos. ${ }^{76}$ Era a lavoura de subsistência que despertava as maiores preocupações e uma das primeiras proclamações da junta pernambucana concitava os pequenos agricultores que haviam ocorrido ao Recife nas suas tropas de milícias a regressarem às suas terras para se empregarem "com o maior desvelo nos trabalhos da agricultura, alargando as mãos na cultura dos víveres". ${ }^{77}$

Nabuco idealizou Dezessete ao pretender que ele fora levado a cabo pela "camada superior da sociedade pernambucana, as antigas famílias, os senhores de engenho, os ricos proprietários, [que teriam sido] os que mais se apaixonaram pela Independência e pela revolução". ${ }^{78}$ No outro extremo, Fernando de Azevedo acentuaria que "a posição da aristocracia rural, nas lutas que agitaram Pernambuco, foi sempre definida: uma atitude de reação conservadora", tanto assim que "na revolução de 1817, quase nenhum senhor de engenho [havia] entre os conspiradores", o que é verdade mas ignora a participação de bom número deles uma vez deflagrada a insurreição. ${ }^{79}$

Nem tanto ao mar nem tanto à terra. Em Dezessete, a participação açucarocrática limitou-se a proprietários rurais da mata norte como tam- 
bém da Paraíba, que eram também produtores de algodão e como tal vitalmente intereressados na preservação da liberdade de comércio, mas não aos da mata sul. Tollenare menciona o fato sintomático de que, em 44 engenhos confiscados devido ao envolvimento dos seus proprietários, a esmagadora maioria situava-se naquela região. ${ }^{80}$ Ao receberem a notícia da insurreição do 6 de março, os capitães-mores e as milícias de Igaraçu, Goiana e Itamaracá marcharam em apoio do Recife. Ao longo do movimento, a mata seca, bem como a várzea do Paraíba, seu prolongamento geográfico, comportaram-se com um zelo que destoou da mata úmida e do seu prolongamento alagoano, nitidamente contra-revolucionários. Malgrado ser o cabeça de numerosa parentela de senhores de engenho da mata sul, Francisco Pais Barreto, morgado do Cabo e futuro marquês do Recife, não logrou recrutá-la para Dezessete, embora lograsse fazê-lo para reprimir a Pedrosada e depois a Confederação do Equador. O que conferiu relevo à ação do grande proprietário territorial, por abastado que fosse, decorreu da circunstância, embora derivada de tal condição, de deter o comando das milícias rurais, razão pela qual tornou-se o alvo do proselitismo maçônico, que habilmente instrumentalizou as relações de parentesco para o projeto revolucionário. Salvo na mata seca e do seu prolongamento paraibano, foi nas áreas não-açucareiras que Dezessete teve contornos eminentemente rurais, como no Crato, sublevado pela clientela da família Alencar, ou no Rio Grande do Norte, onde o movimento foi sobretudo uma empreitada do morgado de Cunhaú, André de Albuquerque Maranhão, dono da maior fortuna da capitania.

$\mathrm{Na}$ época, houve, aliás, quem sobrestimasse o potencial revolucionário da açucarocracia. No seu plano de recolonização do Brasil (1823), Sierra y Mariscal salientava que, para aquele fim, a Coroa portuguesa só poderia contar com o 'partido português', composto sobretudo pelo comércio. Os senhores de engenho não formavam 'ordem', na acepção de corpo privilegiado do Antigo Regime, pois

qualquer pode ser senhor de engenho e há muitas qualidades de engenho [...] Como esta classe de proprietários está sempre no campo, sem o que ficariam perdidos, são muito estúpidos; como não conhecem economia e tampouco conhecem a ordem, tem chegado a maior parte deles a tal estado que 
para comerem carne de vaca duas vezes na semana e terem um cavalo de estrebaria se faz necessário que morram duzentas pessoas de fome, que são os escravos do engenho, a quem lhes dão unicamente o sábado livre, para com o seu produto sustentarem-se e trabalharem o resto da semana para seus senhores.

A seu ver, a açucarocracia pertencia necessariamente ao 'partido democrata', "porque é o partido das revoluçôes e com ela se vêem livres dos seus credores”. Contra este raciocínio, poderia, aliás, virar-se outro dos argumentos do autor. Com efeito, se "a falta de meios" dos senhores de engenho privava-os de "formar clientes e de fazer-se um partido entre o povo, porque eles mesmos são fraquíssimos e precisam da proteção dos negociantes [portugueses] com que se honram muito", ${ }^{81}$ como esperar deles que viessem a desempenhar o papel politicamente desestabilizador que Sierra y Mariscal lhe atribuía?

Não se deve esquecer que, à raiz da derrota da nobreza na guerra dos mascates, a açucarocracia havia-se recolhido à rotina agrária, parte dela desclassificando-se socialmente na esteira da crise setecentista do açúcar. Quando o processo emancipador veio abrir novas perspectivas, sua liderança já não caberá, como cem anos antes, à açucarocracia, mas às camadas urbanas, e ironicamente aos descendentes dos antigos mascates, que representavam a verdadeira gente endinheirada e influente que dava as cartas na capitania nos começos do século XIX e que forneceu vários protagonistas do nosso ciclo revolucionário. Ao ridicularizar as pretensões de domínio da antiga nobreza da terra, "a pueril vaidade dos Albuquerques, Cavalcanti, Lins, Barros, Melos, Regos, Machados, Wanderleys, Barretos, Cunhaús e esses outros que estão sempre a incomodar o mosteiro de São Bento com certidōes de nobreza, brasão de armas, foros, etc.," frei Caneca lembrava que os indivíduos acaudalados da província já não eram eles, mas as famílias de origem mascatal enriquecidas em Pernambuco, razão pela qual muitos daqueles fidalgos não hesitavam em aliar-se pelo casamento com "aqueles que poucos dias antes nos ofereciam de porta em porta alhos, cabolas, marcas de botôes, linhas de Oeiras". ${ }^{82}$ 'Nacionalizados' ao longo de duas ou três geraçôes em membros da burocracia régia, da oficialidade da tropa de linha e do clero secular, constituindo, e "não a nobreza da terra [...] a totali- 
dade dos estudantes universitários de Pernambuco em Portugal", ${ }^{83}$ os descendentes dos mascates, "valorizados pela educação européia, voltavam socialmente iguais aos filhos das mais velhas e poderosas famílias de senhores de terras", de quem eram muitas vezes "seus superiores pela melhor assimilação de valores europeus", ${ }^{84}$ entenda-se, naturalmente mais sensíveis ao ideário político do Iluminismo do que os rebentos açucarocráticos, cuja educação Lopes Gama descrevia com traços crus mesmo depois da criação do curso jurídico de Olinda.

O grande protagonista de Dezessete como de 1822 ou de 1824 não foi a mata açucareira mas o Recife. A existência de uma urbe regional, exercendo sua dominação mercantil do Ceará ao São Francisco, oferecia empecilho de monta para que os interesses agrários pudessem desempenhar o papel de ator principal, caso estivessem convencidos da vantagem da revolução. A própria composição do governo de Dezessete relegou-os à função de coadjuvantes, inclusive a quem, como o coronel Francisco de Paula Cavalcanti de Albuquerque, havia encabeçado quinze anos antes a 'conspiração dos Suassunas'. Desaconselhando as circunstâncias que se desse tempo a que os 'homens do mato' chegassem dos seus engenhos, a junta revolucionária resultou da escolha de dezessete eleitores reunidos às pressas, todos oriundos de camadas citadinas, reduzindo os pró-homens rurais à condição de late-comers. A câmara de Olinda já não podendo ser utilmente instrumentalizada como em 1710-1711 pela decadência a que estava relegada a cidade, e a do Recife pelas suas conexóes com o comércio lusitano, o poder em Dezessete ficou dividido entre cinco diretores, representantes dos principais setores sócio-profissionais, o comércio, a força armada, o clero, os letrados e a lavoura, sendo que Manuel Correia de Araujo, senhor de engenho da várzea do Capibaribe, só aceitou a posição a contragosto, bandeando-se para a contra-revolução logo que foi possível. ${ }^{85}$

Oliveira Lima teve razão ao assinalar que, no plano militar, Dezessete foi liquidado "pelos próprios elementos conservadores e até populares da capitania" ${ }^{86}$ por tal devendo-se entender os senhores de engenho da mata úmida e seus clientes e aderentes, aqueles que o dr. Portugal, deão da Sé de Olinda, designava por "sevandijas do sul”, equiparados na sua condenação aos "escravos do norte", isto é, os cearenses, que não haviam aderido ao 
movimento, salvo no Crato. ${ }^{87}$ Foi em vão que o governo republicano esforçou-se em obter o apoio dos pró-homens da mata sul ou ao menos imunizar a população regional da influência daqueles "aristocratas insensatos que vos fazem guerra para defesa dos seus velhos e carunchosos pergaminhos". A linguagem da proclamação redigida pelo padre Miguelinho é, aliás, reminiscente da que empregara Arruda da Câmara na sua carta de 1810 ao padre João Ribeiro, ao incitá-lo e aos seus amigos a que "não se importem com essa acanalhada e absurda aristocracia cabundá". ${ }^{88}$ Aos açucarocratas do sul, não os motivava a fidelidade monárquica, tão-somente

a baixa saudade que conservam dos seus tortuosos e mal fundados títulos e brasōes, das humildes zumbaias que recebia a sua prostituída e mal fadada senhoria, o horror de se conhecerem iguais em direitos aos outros homens, entre os quais se julgam como uma raça distinta, nascida para mandar, e finalmente o desejo que ainda lhes arde nos orgulhosos coraçóes de vos pisarem e cobrirem de desprezo [...] Essa rançosa e abastardada fidalguia do sul é o vosso único inimigo; o povo que os acompanha ou é seduzido ou arrastado à força; e que podem recear homens livres dessa chusma de escravos, que seguem quatro ou cinco pseudofidalgos sem letras, sem talentos, sem virtude, que não sabem senão vegetar e arrotar embófias e fanfarrices e que não estudaram outra ciência senão a história genealógica de suas arruinadas casas? ${ }^{89}$

Quando a tentativa falhou, o governo republicano rompeu as amarras, proclamando que "os inimigos únicos que temos a vencer sois vós, que, enganados, rejeitais o dom inestimável de uma liberdade racional" 90 .

Também sob este aspecto, Dezessete prefigurou nosso ciclo revolucionário, pois desde então a mata sul, ao contrário da mata norte, transformou-se no baluarte conservador da província. Embora seus capitães-mores e oficiais da milícia houvessem feito inicialmente ato de adesão, a república fora mal recebida ali. Seguindo o exemplo da comarca de Alagoas, onde a causa republicana fora repelida de imediato, a mata úmida formou guerrilhas realistas que, embora batidas em Utinga, lograram isolar o Recife pelo lado do sul, a ponto de os contingentes revolucionários terem de recuar para Candeias e o Exército da Bahia já se encontrar em Sirinhaém enquanto os republicanos ainda o julgavam além do rio Persinunga, prova da "acerba hostilidade de toda a população". ${ }^{91}$ Malgrado dispersar o nú- 
cleo realista de Utinga, o coronel Suassuna absteve-se de sair-lhe ao encalço, consciente de que pisava terreno minado. Quando o exército do sul enviado pelo governo provisório desfez-se diante dos contingentes inimigos em Merepe e Ipojuca, estes já se compunham majoritariamente de efetivos pernambucanos que se lhes haviam agregado, lavradores e condiceiros dos engenhos da região, índios das aldeias alagoanas, a companhia de pardos de Penedo, os quais correspondiam a $65 \%$ do total..$^{92} \mathrm{O}$ exército de Sua Majestade, reconhece Muniz Tavares, "não havia encontrado o mais leve obstáculo na sua marcha; pelos lugares por onde passava, era recebido sem sinais de descontentamento". ${ }^{93}$

\section{Notas}

${ }^{1}$ A. H. de Oliveira Marques. História da maçonaria em Portugal. i, Das origens ao triunfo, Lisboa, 1990, p. 109.

${ }^{2}$ Documentos históricos da Biblioteca Nacional do Rio de Janeiro. ciii, pp.109-10.

${ }^{3}$ Documentos históricos, ciii, pp.109-10; cvii, pp. 201,234, 240, 258.

${ }^{4}$ Oliveira Marques, op. cit., p.74.

${ }^{5}$ L.-F. de Tollenare. Notes dominicales. 3 vols., Paris, 1971-1973, ii, pp.548, 550,592,610.

${ }^{6}$ Dias Martins. Os mártires pernambucanos. Recife, 1853, p. 5; Muniz Tavares. História da revolução de Pernambuco em 1817. 3a. ed., Recife, 1969, p.83.

${ }^{7}$ Dias Martins, op. cit., p.51.

${ }^{8}$ Frei Joaquim do Amor Divino Caneca. São Paulo, 2001, p. 141; Muniz Tavares, op. cit., pp.60-1; Documentos históricos, cv, pp.96-7.

${ }^{9}$ Documentos históricos, cviii, 70, 89.

${ }^{10}$ Tollenare, op.cit., ii, p. 576.

${ }^{11}$ Documentos históricos, cvii, p. 232.

12 "Outros documentos sobre a revolução pernambucana de 1817". Revista do Instituto Histórico e Geográfico Brasileiro, xxx, 1 (1867), p. 117.

${ }^{13}$ João Alfredo Correia de Oliveira. Minha meninice e outros ensaios. Recife, 1988, p. 64;

"Outros documentos sobre a revolução pernambucana de 1817", p. 118.

${ }^{14}$ Outros documentos sobre a revolução pernambucana de 1817 ', p. 118.

${ }^{15}$ Ibid., pp.161-2.

${ }^{16}$ Documentos históricos, ci, p.126

${ }^{17}$ Ibid., civ, p. 154.

18 "Outros documentos sobre a revolução pernambucana de 1817”, pp.121-2. 
${ }^{19}$ Dias Martins, op. cit., p.13.

${ }^{20}$ Francisco Solano Constâncio. História do Brasil, 2 vols., Paris, 1839, ii, p.207.

${ }^{21}$ Muniz Tavares, op.cit., p. 174.

${ }^{22}$ Melo Morais. História do Brasil Reino e do Brasil Império, 2 vols., Belo Horizonte, 1982, i, p. 475. Sobre a pretendida participação do conde dos Arcos, ver Oliveira Lima. D. João VI no Brasil, 3a. ed., Rio de Janeiro, 1996, p. 502; Sebastiāo Pagano. O conde dos Arcos e a revolução de 1817, São Paulo, 1938.

${ }^{23}$ Tollenare, op.cit., iii, p. 863.

${ }^{24}$ Jean-Baptiste de Lesseps ao duque de Richelieu, 20.v.1817; Tollenare, op.cit., iii, p. 897.

${ }^{25}$ Oliveira Lima. D. João VI no Brasil, passim; J. F. de Almeida Prado. D. João VI e o início da classe dirigente do Brasil, 1815-1889. São Paulo, 1968, p.112.

${ }^{26}$ Mello Moraes, op.cit., i, pp. 456-7, 464-6.

${ }^{27}$ Oliveira Marques, op.cit., i, pp.195-6, 291.

${ }^{28}$ Oliveira Marques, op. cit., i, pp. 288-9; Graça e J.S. da Silva Dias. Os primórdios da maçonaria em Portugal, i, 2, Lisboa, 1980, pp. 510,654.

${ }^{29}$ Para a posição da grande burguesia lusitana, Valentim Alexandre. Os sentidos do Império. Questão nacional e questão colonial na crise do Antigo Regime português, Lisboa, 1993, pp. 392-410.

${ }^{30}$ Documentos históricos, iii, pp.110,127.

${ }^{31}$ Tollenare, op.cit., ii, p. 596, iii, p.662.

${ }^{32}$ Revista do Instituto Arqueológico, Histórico e Geográfico Pernambucano, 42 (1948-1949), p. 92.

${ }^{33}$ Dias Martins, op. cit., p. 320.

${ }^{34}$ M. Arruda da Câmara. Obras reunidas, Recife, 1982, p. 259.

${ }^{35}$ Dias Martins, op. cit., pp.320-1.

${ }^{36}$ Muniz Tavares, op.cit., p. 87.

${ }^{37}$ Dias Martins, op.cit., pp.320-1.

${ }^{38}$ Ibid., pp.317-20.

${ }^{39}$ Gonçalo de Mello Mourão. A revolução de 1817 e a história do Brasil. Belo Horizonte, 1996, p. 148.

${ }^{40}$ Sérgio Buarque de Holanda. "A herança colonial. Sua desagregação", História geral da civilização brasileira. O Brasil monárquico.i, Rio de Janeiro, 1962, p.16.

${ }^{41}$ Tobias Monteiro. O Primeiro Reinado, 2 vols., Rio de Janeiro, 1939, i, p.108.

${ }^{42}$ Citado por Mello Mourão, op.cit., p. 260.

${ }^{43}$ Henry Chamberlain a lord Castlereagh, 28.iii.1817, Tollenare, op.cit., iii, pp. 857-8.

${ }^{44}$ Carlos de Alvear a Matias de Irigoyen, 25.iv.1817, Tollenare, op.cit., iii, p.863.

${ }^{45}$ Lord Castlereagh a Lord Stuart, 4.vi.1817, citado por Mello Mourão, op.cit., p. 258. 
${ }^{46}$ Documentos históricos, ciii, pp. 39-40.

${ }^{47}$ Tollenare, op.cit., ii, p. 568.

${ }^{48}$ Documentos históricos, cviii, p. 278.

${ }^{49}$ Tollenare, op.cit., iii, p. 854.

${ }^{50}$ Documentos históricos, cix, p.265.

${ }^{51}$ Tollenare, op.cit., iii, 664; Muniz Tavares, op.cit., p. 36.

${ }^{52}$ Oliveira Lima, notas a Muniz Tavares, pp.317-8.

${ }^{53}$ Muniz Tavares, op.cit., pp.151-2.

${ }^{54}$ Documentos históricos, cviii, pp.277-8.

${ }^{55}$ Dias Martins, op.cit., p.318.

${ }^{56} \mathrm{O}$ projeto de lei orgânica em Documentos históricos, civ, pp.16-23; Muniz Tavares, op.cit., pp.377-83; Frei Caneca, pp. 441-5. Ao publicar o projeto em 1824, frei Caneca observaria que o texto que lhe fora fornecido parecia-lhe que "está truncado, ainda que em poucas coisas", ibid., p.445

${ }^{57}$ Muniz Tavares, op.cit., p.152. Ao escrever sua história de Dezessete, o autor não devia tê-lo à mão, pois o refere como havendo abolido "a pluralidade de indivíduos no poder executivo, o qual devia ser temporário e eleito pela massa dos eleitores”, ibid. Na realidade, o projeto já se achava pronto a 29 de março, quando foi remetido às câmaras para ser aprovado.

${ }^{58}$ Documentos históricos, civ, p. 95. Aqui também a memória traiu Muniz Tavares, para quem o projeto de lei orgânica devia ser objeto apenas de discussão pelos "homens notáveis dos seus distritos", p. 152.

${ }^{59}$ Dias Martins, op.cit., p. 54; Muniz Tavares, op.cit., pp.152-3.

${ }^{60}$ Dias Martins, p. 54. A consulta às Câmaras ao projeto de lei orgânica realizou-se nos primeiros dias de abril, enquanto a declaração sobre os escravos já havia sido feita dias depois do 6 de março, Tollenare, op. cit., ii, p. 568.

${ }^{61}$ Muniz Tavares, op.cit., p. 152.

${ }^{62}$ Dias Martins, op.cit., p. 318.

${ }^{63}$ Ibid., ibid.

${ }^{64}$ Gláucio Veiga. História das idéias da Faculdade de Direito do Recife, i, Recife, 1980, p. 281.

${ }^{65}$ Tollenare, op.cit, ii, p. 568.

${ }^{66}$ Pierre Rosanvallon. Le sacre du citoyen. Paris, 1992, pp. 98-100.

${ }^{67}$ Tollenare, op.cit., ii, p. 575.

${ }^{68}$ François Furet e Mona Ouzouf. Dictionnaire critique de la Révolution française. Acteurs, Paris, 1992, verbete Condorcet. 
${ }^{69}$ Pierre Rosanvallon, op.cit., pp.46ss. Posteriormente, Condorcet admitiria que o proprietário de imóvel urbano pudesse ser assimilado ao proprietário rural.

${ }^{70}$ Tollenare, op.cit., ii, p. 568.

${ }^{71}$ Rosanvallon, op.cit.,p. 61.

${ }^{72}$ Muniz Tavares, op.cit., pp.153-4.

${ }^{73}$ Documentos históricos, ci, p. 155.

${ }^{74}$ Documentos históricos, ci, p.123.

${ }^{75}$ Dias Martins, op.cit., p.320.

${ }^{76}$ Muniz Tavares, op.cit., pp. 114-5.

${ }^{77}$ Documentos históricos, civ, p. 87, cii, p.10.

${ }^{78}$ Joaquim Nabuco. Um estadista do Império. 4a. ed., Rio de Janeiro, 1975, p.113.

${ }^{79}$ Fernando de Azevedo. Canaviais e engenhos na vida política do Brasil. 2a. ed., São Paulo, s/d, pp. 119-20.

${ }^{80}$ Tollenare, op.cit., iii, p.647.

${ }^{81}$ Francisco Sierra y Mariscal. "Idéias gerais sobre a revolução do Brasil e suas conseqüências", 1823, Anais da Biblioteca Nacional do Rio de Janeiro, 43-4 (1920-1921), p. 62.

${ }^{82}$ Documentos históricos, cvii, p.231; Frei Caneca, op. cit., pp.253-6. Como detentores dos manuscritos da "Nobiliarquia pernambucana", redigida em meados do século XVIII por A.J.V. Borges da Fonseca, os beneditinos eram frequentemente solicitados a expedirem certidões de nobreza.

${ }^{83}$ J. A. Gonsalves de Mello. "Nobres e mascates na Câmara do Recife, 1713-1738”. Revista do Instituto Arqueológico, Histórico e Geográfico Pernambucano, 53 (1981), pp. 146-7.

${ }^{84}$ Gilberto Freyre. Sobrados e mucambos. 8a. ed., Rio, 1990, p. 574.

${ }^{85}$ Ao contrário do que afirma Fernando de Azevedo, Manuel Correia de Araujo era um grande proprietário, como senhor do engenho Camaragibe, embora sua família tivesse tido origem mercantil em Pernambuco.

${ }^{86}$ Oiveira Lima. D. João VI no Brasil. p. 513.

${ }^{87}$ Dias Martins, op.cit., p.328.

${ }^{88}$ Arruda da Câmara. Obras reunidas. p. 264.

${ }^{89}$ Proclamação do governo provisório, s/d, Mello Moraes, op.cit., i, 471.

${ }^{90}$ Ibid., 9.v.1817, Mello Moraes, op.cit., i, p.476. Por erro provavelmente de copista, a proclamação aparece dirigida aos "pernambucanos do norte", quando, na realidade, destinava-se aos do sul, como se infere do contexto e das próprias circunstâncias de Dezessete e confirma o depoimento de Antônio Carlos Ribeiro de Andrade, que se refere à proclamação "dirigida aos habitantes do Ceará e aos do sul", redigida pelo padre Miguel Joaquim de Almeida e Castro, "Outros documentos sobre a revolução pernambucana de 1817 ", op.cit., p.136.

${ }^{91}$ Muniz Tavares, op.cit., p.174. 
${ }^{92}$ Ibid., p. 175; Tollenare, op.cit., iii, p. 641; Dias Martins, op.cit.,p.59.

${ }^{93}$ Muniz Tavares, op.cit., p. 174.

\section{Resumo}

$O$ artigo analisa a especificidade e peculiaridade da maçonaria pernambucana, suas divergências em relação aos pedreiros-livres flumineneses, e a participação dos mações na revolução de 1817. Fugindo ao controle do Grande Oriente Lusitano, a maçonaria de Pernambuco esteve no centro dos projetos para o novo governo da capitania, depois da vitória da insurreição. As diferenças entre as várias correntes politicas que abrigava fez com que as propostas para o novo regime pudessem variar muito, passando da radicalidade republicana à restauração do pacto dos Bragança com a capitania. Longe de ser sepatatista, o movimento pretendia preservar a autonomia local no âmbito do Estado que surgisse com o colapso da monarquia absoluta, fosse este um Império constitucional luso-brasileiro ou uma monarquia liberal na antiga América Portuguesa.

\section{Abstract}

This article analyses the specific characteristics of the Masonry of the state of Pernambuco, in particular its divergences with the Mansonry of the state of Rio de Janeiro and the participation of freemasons in the Revolution of 1817. The Pernambucan Masonry escaped the control of the Grande Oriente Lusitano and, after the triumph of the insurrection, played a key role in the formulation of new projects for the government of the capitania. Given the ample spectrum of political forces it hosted, its political proposals for the new regime ranged from the republican radicalism to the restoration of the pact of the Braganças with the capitania. Rather than cultivating separatism, it intended to preserve local autonomy in the face of the new state that would presumably emerge from the collapse of the absolutist monarchy, be it a constitutional Luso-Brazilian empire or a liberal monarchy based on the former Portuguese possessions in America. 